\title{
COMMUNity SOCIAL RESPONSIBILITY (CSR) APPROACH TO THE COMMUNITY DURING THE COVID-19 PANDEMIC
}

International Journal of Innovation Review

https://ijireview.com/ijir

e-ISSN:

p-ISSN:

IJIR REVIEW 1 (1) (2020): 53-59

DOI:

Keywords: Pandemic, Covid-19, CSR in New Normal, Corporate Public Relations, Social, and Environment.

\section{* Corresponding Author \\ Phone : \\ Email : kadekdellach@gmail.com}

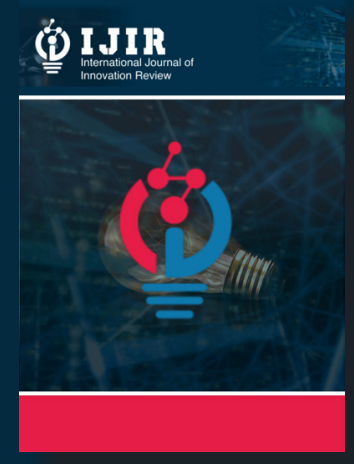

(C) Della Choirunnisa

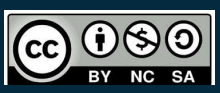

This work is licensed under the Creative Commons AttributionNonCommercial-ShareAlike 4.0 International License.

\section{Della Choirunnisa*}

Faculty of Social and Political Sciences,

Airlangga University, Surabaya

Jl. Airlangga No.4 - 6, Airlangga, Gubeng, Surabaya, Jawa Timur 60115

Received: 18 July 2020; Accepted: 10 August 2020; Published online: 30 September 2020

\begin{abstract}
A good company is not only focused on making profits economically to enrich the company itself, but the company also has a contribution, both in the form of concern for natural conditions and also the welfare of the community. Understanding related to Corporate Social Responsibility (CSR), in general, always revolves around three main things, namely voluntary (voluntary), companies can also set aside a part of their profits to be used in the context of philanthropy, and as a form of obligation. ) company. These three things during this pandemic were used as an excuse for force majeure. Even though the company is still able to carry out the normal production process as usual. The method used is descriptive qualitative analysis method with literature study. When the enforced new normal is, the Corporate Social Responsibility (CSR) can carry out its duties again as before by implementing health protocols by complying with the rules of the late stipulated SOP. The existence of a pandemic is a great opportunity for Corporate Social Responsibility (CSR) to be actively involved during the crisis and to become a catalyst for a new era in the development of Corporate Social Responsibility (CSR) for the long term.
\end{abstract}

\section{INTRODUCTION}

In the corporate world, the term Corporate Social Responsibility (CSR) began to appear since the 1970s and has become increasingly popular from year to year, especially when the book entitled Cannibals With Forks: The Triple Bottom Line in 21st Century Business (1998) was written. by John Elkington. The book explains how to develop three important components of sustainability development, namely economic growth, environmental protection, and social equity, which was initiated by the World Commission on Environment and Development (WCED) in the Brundtland Report (1987). Elkington divides Corporate Social Responsibility (CSR) into three focuses, known as 3P, profit, planet, and people. This means that a good company is not only focused on reaping economic benefits to enrich its own 
company, but companies also have a contribution, both in the form of concern for natural conditions and also for the welfare of the community.

CSR in Indonesia became increasingly recognized in the 1999s. Several companies in Indonesia have carried out a corporate social activity program long before, but do not know the term CSR. The way they work is done is also similar to the way CSR works. is a form of company concern for the natural environment and the social environment of the community. The social concern carried out by CSR is motivated by the impact that will be obtained, namely "for better or worse" for the environmental and socio-economic conditions of the community, especially for those who live near the company. Besides, the presence of Corporate Social Responsibility (CSR) is also for stakeholders (people who have an interest in the company's existence). In this case, stakeholders can include the following employees and their families, customers, suppliers, communities living around the company, nongovernmental organizations, mass media, and the government (Suharto, 2008).

Corporate social responsibility or Corporate Social Responsibility (CSR) has been legally stated in Law No. 40 of 2007, regarding Limited Liability Companies. The law describes the social and environmental responsibility of companies for their existence in business activities. Today, facing the impacts of globalization, advances in information technology, and market openness, companies must seriously pay attention to Corporate Social Responsibility (CSR). To protect the company from various risks of lawsuits, as well as the risk of loss of partners business and the risk of corporate image (brand risk) which is not only sufficiently compliant with laws and regulations. On the other hand, national and international pressures influence corporate business behavior. This pressure also comes from shareholders, NGOs (Non-Governmental Organizations), and business partners (especially from countries whose business communities are sensitive to Corporate Social Responsibility (CSR) and advocates who take part in fighting for the public interest (Mapisangka). , 2009).

Several studies also highlight this, Badjuri (2011) states, the implementation of Corporate Social Responsibility (CSR) in Indonesia depends on how the top leadership of a corporation is. This means that the policy is Corporate Social Responsibility (CSR)not guaranteed to be in line with the vision and mission of a corporation. If the leadership of the company has a high level of moral awareness, they will likely be able to implement a policy Corporate Social Responsibility appropriate and correct(CSR). But also on the contrary, if only oriented to the interests of shareholder satisfaction such as high productivity, large profits, and high share value and only focuses on personal achievement, the policy Corporate Social Responsibility (CSR)is just cosmetic. The understanding of companies about the concept of Corporate Social Responsibility (CSR) is still diverse, one of which is due to the lack of literature available (Badjuri, 2011).

There are several main things related to Corporate Social Responsibility (CSR) including: first, namely a voluntary role. Where there is a company that helps to overcome a social and environmental problem, especially those close to the company, therefore the company can have a free will related to doing or not doing this role.

Second, in addition to a company as a profit institution, a company can also set aside a portion of its profits to be used in the context of philanthropy, which has the aim of empowering the society and improving in the event of environmental damage due to exploration and exploitation activities carried out by the company.

Third, Corporate Social Responsibility (CSR) or corporate social responsibility as a form of obligation (obligation) companies to always care about a problem by alleviating the ever-increasing humanitarian and environmental crisis.

The next understanding of Corporate Social Responsibility (CSR) is based on the premise that it is not only the government that can solve problems, through the establishment of public policy (public policy). But companies must also have a responsibility for how social problems arise. An effort is also encouraged to take an active approach to sustainable development.

The concept of Corporate Social Responsibility (CSR) is also based on the morale of the company. A company canıt live in a vacuum and live in isolation. Companies will live side by side with the environment. Companies develop around communities that are in direct contact with the company (Marnelly, 2013).

The emergence of the Corona Virus Disease 2019 (Covid-19) pandemic, prompted the Indonesian government to take policy actions social distancing (maintain social distancing and avoid crowds), then physical distancing. This policy was able to drastically reduce the activity and movement of people in big cities in Indonesia, especially in Jabodetabek.

For example, an intercity bus company has stopped up to $80 \%$ of its fleet from operating again in March 2020. PT KAI has also canceled 44 travel routes from Jakarta to cities in Java during April (Subekti \& Yulianto, 2020).

Another crucial issue is the policy set out in PP. 21 of 2020 is related to the PSBB (Large-Scale Social Restrictions), which aims to break the chain of spreading Covid-19. This policy has resulted in the termination of employment by many companies, 
as a step to reduce losses caused by Covid-19. Not a few companies in Indonesia have to carry out layoffs (PHK) on a large scale. The termination of employment by these companies is related to Articles 164 and 165 of Law No.13 of 2003 concerning Manpower which states that a company has the right to terminate its working relationship with employees if a company experiences a loss.

Goldston (2020) concludes that when a pandemic occurs, companies must be able to reflect on a positive outlook. If leaders take precautionary steps to protect the company's workforce, profits will follow. Such as working remotely can increase efficiency, because there has been a reduction in time for physical and social distancing.

Termination of employment during the Covid-19 pandemic was used as an excuse for force majeure by the company. Even though the company is still producing normally. The terms of termination of employment are when the company experiences a decline or loss for 2 years. Meanwhile, the Covid-19 pandemic has not been 2 years. The policy is force majeure a question of whether it is a natural disaster or not. The reason for force majeure used by several companies to terminate employment relations cannot be justified. Seeing the massive economic disruption due to the Covid-19 pandemic, workers should get clear legal protection (Juaningsih, 2020).

On the other hand, COVID-19 pandemic has a positive impact on companies engaged in environmental health and hygiene. For example, a company that produces hand sanitizers, hand soap, and wet tissue. For example, the CEO \& CO of the SIRCLO Foundation, Brian Marshal.

Hand sanitizer sales increased by $531 \%$. Hand soap sales increased by $304 \%$, wet tissue sales increased by $210 \%$. Sales of vitamin products also increased by $242 \%$.

Another example, a company engaged in the pharmaceutical sector (drug production). Among these companies that experienced an increase in shares were: 1). Inovio: Their share value has doubled. The vaccine they make is INO-4800. 2). Modern: their share has increased by $42 \%$. 3). Novavax: When their company shared information that there was a development in vaccine search research a few weeks ago, their share also increased by $20 \%$. 4). Mask companies, for example, sales of masks with the Unicharm brand have also increased quite fantastically up to 10 times or $1000 \%$, and sales of masks with the Kowa brand have also increased significantly by increasing by $90 \%$ ).

Another example, the ventilator company Mindray Bio-Medical Electronics Co also experienced an increase of up to $41 \%$. In addition to the drastically increasing share, the company owners also get extraordinary profits. An example is the accumulation of the increase in wealth experienced by the three founders of the company, namely Li Xiting, Xu Huang, and Cheng Minghe, which is estimated to have made a profit of up to 7.3 billion US dollars (Rohmah, 2020).

\section{METHOD}

This research uses a descriptive qualitative method with a literature study. This method is used to provide an analysis of data related to the effect of the work program Corporate Social Responsibility (CSR) amid a pandemic. The data source uses some literature and journals related to the work program Corporate Social Responsibility (CSR). Data analysis techniques are performed by describing, processing, analyzing data, interpreting data based on factors and impacts, then making conclusions.

\section{RESULTS AND DISCUSSION}

To deal with the spread of the COVIDvirus outbreak, the Government requires social restrictions, as an effort_taken to break the chain of spread and control of the virus. When rules are social distancing enforced, everyone is prohibited from touching and is required to maintain a distance of 1-2 meters. With the enactment of these rules, there are also several examples of the process of implementing social distancing that was generally enforced during this pandemic, namely by working from home or better known as work. from home; learning is done from home for school students and university students; not holding meetings or events that will later be attended by large numbers of people or create a crowd; do not visit anyone who is sick, all contact can be done simply by a phone call or online.

According to Ebrahim and Buheii (2020), the most important tool to use during an emergency crisis is a communication model. The communication model is very important to use during the current pandemic crisis, which requires collective responsibility and engagement with effective responses. When facing the challenges of Covid-19, the communication model encourages integrated group thinking related to group vulnerability in the future. The targets used in the communication model can also be developed through strategic mechanisms that have interrelated relationships that can strengthen the company and its psychological well-being.

Based on research conducted through observations it says that prevention which is done through rules social distancing is deemed not capable or successful enough in the process of breaking the chain of spreading the Covid-19 virus. This can be proven by data that the number of positive Covid-19 people is increasing day by day. Moreover, the regulation of the government 
policy to keep your distance is also not a policy without risks. With the existence of regulations to maintain social and physical distance for a relatively long period, it can cause a decrease in the process of economic production activities (supply shock). The regulation of the process of limiting social and physical interactions that are carried out can lead to a reduction in the amount of production of goods which is quite crucial. This also affects the entire process of company activities, including activities carried out by Corporate Social Responsibility (CSR), which are often stopped due to direct physical contact with many people directly.

Whether or not these rules affect the process of being carried out, what is clear is that maintaining distance is an action that is felt to be the most likely to be chosen by anyone to avoid the spread of the Covid-19 virus. Policies carried out by developed countries such as the United States and countries in Europe also feel difficult in dealing with the problem of the spread of the Covid-19 virus. Moreover, for developing countries such as Indonesia, which has a pluralistic society, it will be very difficult to control all activities carried out to break the chain of Covid-19 spread so that it does not expand and can return to normal activities (Khaeruman et al., 2020).

New normal is a scenario used to accelerate the handling of Covid-19 in the health and socioeconomic aspects by the government to implement the scenario from new normal by considering epidemiological studies and regional readiness (Putsanra, 2020). Local governments are allowed to apply the new normal process if they feel their regions are at a moderate level, by being required to prepare SOPs to be used in the new normal scenario. By referring to several indicators such as; a) Not increasing the number of infections or not expanding the transmission or as much as possible to reduce transmission. b) Using health system indicators through how high the adaptation and capacity of health services are in responding to the Covid-19 service process. c) Surveillance is a way to tell a person or even a group of people whether it has the potential to cause Coovid-19 or not so that massive testing is carried out.

Related to the new normal protocol by issuing the Decree of the Minister of Health Number HK.01.07 / MENKES / 328/2020 concerning Guidelines for Prevention and Control of COVID-19 in Office and Industrial Workplaces in Support of Business Continuity in Pandemic Situations. Minister of Health Terawan Agus Putranto said that in the business world and the working community can have a major contribution in the process of breaking the chain of transmission, this is due to a large number of the working population and a large amount of mobility that occurs, as well as population interactions generally caused by work activities. For this reason, after the implementation of the PSBB process with the COVID-19 pandemic conditions that still exist, it is necessary to make efforts in the form of mitigation and workplace readiness as optimally as possible so that it is hoped that it can adapt through regulations on changing lifestyle in the COVID-19 or New Normal situation.

These are steps that can be applied by office employees to stay active when the new normal is enforced so that they can live side by side with the current pandemic. Of course, the existence of the new normal regulations can also make it easier for Corporate Social Responsibility (CSR) to continue to carry out its duties daily. Of course, with the current pandemic, Corporate Social Responsibility plays a (CSR)very important role in restoring current conditions, especially the conditions shock with the Covid-19 virus which will certainly leave traumas or fears to live normally again as before, of course. now live back to normal by observing the established health protocol. The role of Corporate Social Responsibility (CSR) is needed to help restore the chaos that is currently being experienced by Indonesia, especially in the socio-economic aspects, such as job loss, not being able to meet daily needs, and the current state of problems.

The process of spreading the Covid-19 virus has always experienced an increasing number of days so that it can affect the global economic pace. Many studies have stated that the economic rate will experience a slow condition concerning the value of the Gross Domestic Product (GDP) which is expected to last until 2021. A crisis that has occurred, as experienced, will certainly have a reduced impact on various sectors, one of which is the economy. , one of which is also affected is the existence of MSMEs which also really need special attention, this is because MSMEs are the largest contributor to Gross Domestic Product (GDP) and can be used as a mainstay in terms of absorption of unemployment, substitution in the production of consumer goods, substituting for production of goods consumption or semi-finished. Here, MSMEs have a very important role in the success of the economy in Indonesia. Data from the Ministry of Cooperatives and Small and Medium Enterprises of Indonesia in 2018 shows that the number of business units in MSMEs is $99.9 \%$ of the total business units or 62.9 million units. The absorption capacity of MSMEs is $97 \%$ of the total employment that can occur, $89 \%$ of which is in the micro sector, and can contribute up to $60 \%$ of gross domestic product.

There was economic turmoil that occurred so extraordinary, but MSMEs were always considered capable of facing an economic slowdown related to current conditions. As stated by the Chairperson of the Indonesian MSME Association (Akumindo) Ikhsan Ingrabatun, he estimates that the turnover 
obtained by MSMEs in the non-culinary sector has decreased to reach $30-35 \%$ since the existence of Covid-19 which is the cause of the sellers who are only able to rely on eye contact. face or face-to-face meeting between the seller and the buyer physically. With the issuance of appeals from the Government regarding issues social The distancing which is launched starting on March 15, 2020, is also expected to have a serious impact on the sales process of MSME products so as not to experience a decline. Therefore, more attention is needed from the government to the MSME sector as we know that MSMEs are the main drivers of the nation's economy.

Not only the things mentioned above, that the impact of the existence of Covid-19 has also changed the business behavior of business actors in the process of running a business they are doing. Although the impact of the existence of Covid-19 can be felt by various parties, especially in the industrial sector, this does not mean that MSME players have to stop in the process of running their business. However, MSMEs can still strive to continue running their business through an online system (e-marketing) by utilizing various kinds of social media and other online shopping places, so that this will not be said to have violated government regulations regarding applicable social distancing rules.

Through a role from the use of technology in business activities and the process of distribution of goods, it can still be carried out smoothly. This is also done with the high hope that as much as possible the MSME business will not just stop and the distribution of goods will continue. There is also another new norm for a businessman when he has to face the Covid-19 pandemic which requires business people to be able and must be technology literate. It is also hoped that this will continue to apply until post-COVID-19, which requires MSME players to make recovery, even to be able to adapt to new norms that require every business actor to have close contact with technology (Awali, 2020).

By knowing the current condition of MSMEs which is experiencing a decline, this is where Corporate Social Responsibility (CSR) is needed. Perhaps this can be expressed in his work program, that the current Corporate Social Responsibility (CSR) has always succeeded in carrying out continued empowerment. Special attention is not only able to be given by the government, but also from the companys Corporate Social Responsibility (CSR) to always help to ensure the success of existing MSMEs. Coaching especially during the current pandemic is very much needed. Each MSMEs can be assisted in the process of knowledge or information related to the online marketing process, or the Corporate Social Responsibility (CSR) of a company has other innovations to avoid a decrease in the sales turnover of MSMEs.

Corporate Social Responsibility (CSR) also often creates MSME independence programs through work programs that will be monitored periodically or continuously until they feel able to be independent or free from supervision or from providing financial assistance by Corporate Social Responsibility (CSR), but these MSMEs remain still under the supervision of the companys Corporate Social Responsibility (CSR). MSMEs are also included in the PKBL (Community Development Partnership Program) program with a capital rotation system, if MSMEs is deemed successful and capable of being independent, then the MSMEs must return the capital that has been used to be reused in the establishment of other MSMEs.

He and Harris (2020) provide some initial thought options related to how the ongoing pandemic has affected Corporate Social Responsibility (CSR), precisely in the article it states that a pandemic is a great opportunity for Corporate Social Responsibility (CSR) to be actively involved during the crisis. and become a catalyst for a new era in the development of Corporate Social Responsibility (CSR) for the long term. Changes also affect beliefs, attitudes, and opinions so that activities can be carried out with ingenious strategies for reflection.

When the new normal is enforced, the Corporate Social Responsibility (CSR) can carry out its duties again as before by implementing health protocols by complying with the rules of the late stipulated SOP. The current Covid-19 pandemic plays a role in Corporate Social Responsibility very decisive(CSR) in helping the sustainability of peopless lives, especially those who live around companies to continue their lives. Corporate Social Responsibility (CSR) can participate in the successful implementation of the new normal and can also play an active role in helping to break the chain of the spread of the Covid-19 virus through the work programs provided. The efforts that have been made by Corporate Social Responsibility (CSR) amid the current pandemic can also have a very large positive impact on the company as expected, namely by building a positive image by all parties towards the company. That every company can measure its form of concern through financial efforts made by Corporate Social Responsibility (CSR).

\section{Conclusion}

Based on research conducted through observations, it is said that prevention efforts carried out through social distancing rules are deemed not 
sufficient or successful in the process of breaking the chain of the spread of the Covid-19 virus, this can be proven by data that the number of positive Covid-19 cases is increasing day by day. Whether or not these rules affect the process of being carried out, what is clear is that maintaining distance is an action that is felt to be the most likely to be chosen by anyone to avoid the spread of the Covid-19 virus.

New normal is a scenario that is used to accelerate the handling of Covid-19 in the health and socio-economic aspects by the government to implement the scenario from the new normal by considering epidemiological studies and regional readiness. Of course, with the current pandemic, Corporate Social Responsibility plays a (CSR)very important role in restoring current conditions, especially the conditions shock with the Covid-19 virus which will certainly leave traumas or fears to live normally again as before, of course. now live back to normal by observing the established health protocol. The crisis that has occurred, as experienced, will certainly have a reduced impact on various sectors, one of which is the economy, one of which is also affected by the existence of MSMEs which also need special attention, this is because MSMEs are the largest contributor to Gross Domestic Product. (GDP) and can be used as a mainstay in terms of absorption of the number of unemployed, substitution in the production of consumer goods, substituting the production of consumer goods or semi-finished goods.

As stated by the Chairperson of the Indonesian MSME Association (Akumindo) Ikhsan Ingrabatun, he estimates that the turnover obtained by MSMEs in the non-culinary sector has decreased by up to $30-35 \%$ since the existence of Covid-19 which is the cause of which are sellers who are only able to rely on face to face or a direct meeting between the seller and the buyer physically.

Corporate Social Responsibility (CSR) also often creates MSME independence programs through work programs that will be monitored periodically or continuously until they feel able to be independent or free from supervision or from providing financial assistance by Corporate Social Responsibility (CSR), but these MSMEs remain still under the supervision of the company>s Corporate Social Responsibility (CSR). When the new normal is enforced, the Corporate Social Responsibility (CSR) can carry out its duties again as before by implementing health protocols by complying with the rules of the late stipulated SOP.

\section{REFERENCES}

Awali, H. (2020). Urgensi Pemanfaatan E-Marketing pada Keberlangsungan UMKM di Kota Pekalongan di Tengah Dampak Covid-19.
BALANCA : Jurnal Ekonomi Dan Bisnis Islam, 2(1), 1-14. https://doi.org/10.35905/balanca. v2i1.1342

Badjuri, A. (2011). Faktor-Faktor Fundamental, Mekanisme Coorporate Governance, Pengungkapan Coorporate Social Responsibility (CSR) Perusahaan Manufaktur Dan Sumber Daya Alam di Indonesia. Dinamika Keuangan Dan Perbankan, 3(1), 38-45. https://www.unisbank.ac.id/ojs/index.php/ fe1/article/view/2064

Goldston, J. (2020). Pandemically Speaking: Sustaining Corporate Social Responsibility During Times of Uncertainty. International Research Journal of Engineering and Technology (IRJET), 7(6), 5514-5518. https://www.irjet. net/archives/V7/i6/IRJET-V7I61036.pdf

He, H., \& Harris, L. (2020). The impact of Covid-19 pandemic on corporate social responsibility and marketing philosophy. Journal of Business Research, 116(August), 176-182. https://doi. org/10.1016/j.jbusres.2020.05.030

Husain Ebrahim, A., \& Buheji, M. (2020). A Pursuit for a 'Holistic Social Responsibility Strategic Framework' Addressing COVID-19 Pandemic Needs. American Journal of Economics, 10(5), 293-304. https://doi.org/10.5923/j. economics.20201005.04

Juaningsih, I. N. (2020). Analisis Kebijakan PHK Bagi Para Pekerja Pada Masa Pandemi Covid-19 di Indonesia. Buletin Hukum Dan Keadilan, 4(1), 189-196. https://doi.org/10.15408/adalah. v4i1.15764

Khaeruman, B., Nur, S., Mujiyo, M., \& Rodliyana, D. (2020). Pandemi Covid-19 dan kondisi darurat: Kajian hadis tematik [UIN Sunan Gunung Djati]. http://digilib.uinsgd.ac.id/30777/

Mapisangka, A. (2009). Implementasi CSR terhadap Kesejahteraan Hidup Masyarakat. Jurnal Ekonomi Dan Studi Pembangunan, 1(1), 3947. http://journal.um.ac.id/index.php/jesp/ article/view/5123

Marnelly, T. R. (2013). Corporate Social Responsibility (CSR): Tinjauan Teori dan Praktek di Indonesia. Jurnal Aplikasi Bisnis, 3(1), 49-59. https://jab.ejournal.unri.ac.id/ index.php/JAB/article/view/910

Putsanra, D. V. (2020). Apa Itu New Normal dan Bagaimana Penerapannya Saat Pandemi Corona? . Tirto.ID. https://tirto.id/apa-itunew-normal-dan-bagaimana-penerapannyasaat-pandemi-corona-fCSg

Rohmah, S. N. (2020). Adakah Peluang Bisnis di Tengah Kelesuan Perekonomian Akibat Pandemi Coronavirus Covid-19? ADALAH, 4(1), 63-74. http://journal.uinjkt.ac.id/index.php/ adalah/article/download/15448/7222 
Subekti, R., \& Yulianto, A. (2020). Sudah Pesan Tiket? Perhatikan Pembatalan Jadwal Kereta Ini. Republika.Co.Id. https://republika.co.id/ berita/q7kq72396/sudah-pesan-tiketperhatikan-pembatalan-jadwal-kereta-ini
Suharto, E. (2008). Menggagas Standar Audit Program CSR. Docplayer.Info. https:// docplayer.info / 29685317 - Menggagas standar-audit-program-csr-initiating-auditstandard-of-csr-program.html 